\title{
On New Forms of Science Communication and Communication in Science: $A$ Videographic Approach to Visuality in Science Slams and Academic Group Talk
}

\author{
René Wilke' and Miira Hill ${ }^{2}$
}

\begin{abstract}
In this article, we focus on the communicative character of visuality and visual representations ("visuals") in transdisciplinary science communication (science slams) and interdisciplinary communication within science (group talks). We propose a methodology for the study of visuality and the use of visuals as communicative actions. Both unfold within a triadic structure of social actors and the objectivations they (re-)produce. Therefore, we combine the approach of videography and focused ethnography. This research design allows not only putting actions under an audiovisual microscope but also to combine ethnographic knowledge stemming from fieldwork with the audiovisual analysis in front of screens. Using data from our empirical fields (science communication in science slams as well as communication within science in group talks), we illustrate the vital role of visuality of new practices in the communicative construction of (scientific) reality. In doing so, we also emphasize the importance of audiovisual methods for qualitative empirical social research today.
\end{abstract}

\section{Keywords}

videography, focused ethnography, communicative construction, science communication, visualization, interdisciplinarity, transdisciplinarity

\section{Introduction}

In our study of science communication, we propose a methodological framework for analyzing visuality and the use of visuals ${ }^{1}$ as "communicative actions" (Knoblauch, 2014 , p. 159) and demonstrate how we conduct research in the field of science through a videographic approach triangulated by expert interviews. Specifically, we analyze the face-to-face-communication and intersubjective validation of new scientific knowledge during communication processes in science slams and within the weekly group talks of a research team operating in the field of computational neuroscience (CNS). We focus particularly on the multimodal process of embodied communicative action by which (scientific) reality is built up in historical chains of interaction (Collins, 1998).

In contemporary science communication, we are witnessing a shift toward intercontextuality and translation. That puts pressure on speakers or lecturers, whose opportunities of communication have increased at the price of being bound to new standards. We would like to show how communication changes through the shift from a linear text (re-)producing "speaking machine" (Goffman, 1981) to the contemporary multireferential magicians of science communication involved in transdisciplinary science slams or interdisciplinary group talks. To understand these shifts, we combine two approaches: focused ethnography (Knoblauch, 2014) and videography (Knoblauch, Tuma, \& Schnettler, 2014) to evaluate how the shift in institutional structures plays out in communicative actions and vice versa.

After a prologue on science and science communication, which explains the necessity for our research, we explain our methodological strategy. Following this outline, we briefly introduce the reader to our fields of investigation. Then we relate our empirical findings on visuals and communicative action in science communication. Based on these findings, we summarize new forms and challenges for science communication in the context of the current

\footnotetext{
'Technische Universität Berlin, Germany

${ }^{2}$ Leuphana University of Lüneburg, Germany

Corresponding Author:

René Wilke, Institut für Soziologie, Technische Universität Berlin, Fraunhoferstraße 33, 10587 Berlin, Germany.

Email: rene.wilke@tu-berlin.de
} 
"Kommunikationsgesellschaft" [English: "communication society"] (Knoblauch, 2017, pp. 329-377) as a problem of legitimacy. We close with an evaluation of our findings and the implications of our research for the methodology of science research and qualitative research practice in general.

\section{Communication, Visuality, and Embodied Action: Interdisciplinarity and Transdisciplinarity as Problems for Science Research}

By focusing on the visual, the social sciences have responded to a paradigm shift that was promoted most prominently in cultural sciences (Mitchell, 1992) and the humanities (Boehm, 1994). Mitchell and Boehm bemoaned - each within their cultural diagnostic framework - the lack of analytic attention to a crucial medium of constructing (social) reality: visuality. A great deal of social scientific research on visuality has since been conducted. Empirical findings in the field of science and technology studies (STS) soon suggested that visuals in science are generated and interpreted by people who communicate in social processes (Alać, 2008; Amann \& Knorr-Cetina, 1990; Beaulieu, 2002; Lynch, 1988). Production and interpretation processes have been described as visual and esthetic practices that are influenced by the intentions of the actors (Latour, 1990), the materiality of the representational devices used (Tibbetts, 1988), by already objectified knowledge (Woolgar, 1990), and by public dissemination strategies, forexample, insciencejournalism(Molek-Kozakowska, 2018). Also, the correspondence between individualizing and responsibilizing societal structures and the activation of subjects through visual strategies has recently come under scrutiny (Engel, 2018). Hence, what is visible and what can be seen is sociological (Fleck, 1935/2011; Goodwin, 1994) and built up in processes of communicative action (Knoblauch, 2013a, 2017).

Even if STS researchers have already made STS the leading source of public insight into science-in-action (Yearley, 1994), a lot of research has yet to be done. Scholars have already addressed the problem that past STS research on science communication was "disembodied" (Davies, 2009, 2013) - a lack we now seek to overcome by stressing the active, communicative, and therefore bodily character of everyday accomplishments in scientific life. A handful of scholars also focused on kinaesthetic and affective entanglements in science communication (Myers, 2008, 2012) or on aspects of body movement and sociotechnical arrangements in (science) communication (Goffman, 1981; Goodwin, 1981; Hedenus, 2016; Kiesow, 2016; Knoblauch, 2007; Ochs, Gonzales, \& Jacoby, 1996; Tuma, 2012). These studies are right in closely connecting what social constructivists call objectivations (Berger \& Luckmann, 1966) to the human body and its performance in social situations. Other work is explicitly devoted to visuals as elements of scientific talk (e.g., Rowley-Jolivet, 2004) and public science communication (Trumbo, 1999, 2000). Yet, despite these studies, more research is needed to understand the processes by which (scientific) knowledge comes to be (inter- or transdisciplinarily) socially established as reality. These are embodied processes of "communicative action" (Knoblauch, 2014, p. 159) highly interwoven with visuals and visual practices, especially, in the growing areas of inter- and transdisciplinarity. Before we introduce our methodological and theoretical framework, we therefore need to describe general transformations of the scientific landscape, which is characterized by a strong political imperative for inter- and transdisciplinarity.

\section{"Modes" of Communication and the Problem of Legitimacy}

According to Thomas Kuhn (1972), a feature of modern science is that knowledge is produced in relatively closed communication and argumentation communities, composed of relatively small groupings of specialist colleagues. Every community produces the truths about its subject matter in self-government. The metaphor of "academic tribes" (Becher \& Trowler, 2001) has therefore been widely used to characterize differentiation in science. As a result of communicative closure, professional associations have developed different and often incompatible criteria for presenting and assessing new knowledge within their "epistemic cultures" (Knorr-Cetina, 1999/2002).

Research policy actors were already critical of a (supposed) tendency of fragmentation of academic knowledge cultures in the 1970s. They feared that the professional associations would impose limits on their own knowledge as part of their communicative closure. Since then, the demand for more interdisciplinarity has been a constant in research policy. The term interdisciplinarity was coined by the organisation for Economic Co-operation and Development (OECD) to describe different teaching and research formats that serve to exchange models, methods, and persons between subject areas. At OECD meetings, economists, politicians, and philosophers of science argued that interdisciplinary formats were better suited to dealing with interdisciplinary research questions and, by extension, the problems of the real world (Gibbons et al., 1994, pp. 147-149).

According to a number of prominent sociological diagnoses labeled "mode 2" (Gibbons et al., 1994; Nowotny, 2003; Nowotny, Scott, \& Gibbons, 2001), institutional reforms did not fail to meet their research policy goals. The authors of these studies diagnosed that professional associations were increasingly losing their orientation and control 
functions in the production of knowledge. The authors even saw that these functions were being transferred to a projectoriented "context of application" (Gibbons et al., 1994, pp. 3-8). Within this framework, researchers are increasingly switching from disciplinary "mode 1" to "mode 2," orienting their research activities to inter- or transdisciplinary research problems and social contexts of application (e.g., politics, business, social movements).

At the same time, modern science has had to adjust to the demands of becoming increasingly public. Science not only is required to be interdisciplinary but now also has to be transdisciplinary. In a civil society that is knowledge-oriented and that increasingly understands itself as innovative, communicative, and participatory, the necessity to gain public affirmation and legitimacy is growing (Hill, 2015). In the uncertain and complex relationship between different subject areas and science and the public, new forms of communicative action have emerged. Knowledge communication has an important role in contemporary knowledge-based societies. The dominance of knowledge work in industry has resulted in a strong societal orientation toward scientific knowledge. A consequence of this development is the need to communicate knowledge to other fields. The increase of communications then requires the translation of knowledge both between science and nonscientific institutional fields (transdisciplinary) and between different scientific fields (interdisciplinary).

A problem of communication arises from the expectation that science should have a straightforward connection to the public. Early critics called the gap between the scientific community and the public a "gulf of incomprehensibility" (Shapin, 1990, p. 994). For the critics, this gulf was proof of the misleading effects of scientific discourse. The inability to communicate to a nonscientific audience falls short of the perceived responsibility of the scientific enterprise to relate to society at large. A further problem is that of legitimacy: Today, scientists feel a need to legitimate their activities not only to their own community or the wider public but also to other scientific fields. The less knowledge is shared, the more needs to be communicated (Knoblauch, 2008).

\section{Methodological Approach: Combining Videography and Focused Ethnography}

Our theoretical and methodological framework is built on central assumptions of interpretive sociology. From this contextual perspective, the accentuated role of informatization, digital media, and performance in the face-to-facecommunication of scientific knowledge is taken into account. On the basis of empirical data, new forms of producing and presenting scientific knowledge are reconstructed, which are closely related to new patterns of the scientific persona.
We have argued that the rise of a "Kommunikationsgesellschaft" [English: "communication society"] (Knoblauch, 2017, pp. 329-377) raises the institutional pressure on science to produce and present knowledge with interdisciplinary or nonscientific relevance, with the increase of visuals being one response to such communicative demands. To deepen our understanding of such processes, we turn to embodied communicative processes and focus on the understudied area of visuals in inter- and transdisciplinary science communication. We discuss some findings of two different research projects, supported by the German Research Foundation (DFG), on transdisciplinary science communication (Hill, 2016, 2017) and interdisciplinary communication in science (Lettkemann \& Wilke, 2016; Wilke \& Lettkemann, 2018; Wilke, Lettkemann, \& Knoblauch, 2018). Both terms refer to the communication (and partly intersubjective validation) of scientific knowledge. Part of our aim in writing this article is to merge the two perspectives: first, the public communication of scientific knowledge (transdisciplinary science communication; Nowotny et al., 2001) and second, the communication of knowledge within a highly interdisciplinary structured scientific research group (interdisciplinary communication in science). For the sake of simplicity, we will refer to both instances of communication as science communication: Whenever scholars or scientists talk to each other or to a nonacademic public and whenever they refer to their scientific expertise on these occasions and insofar as this reference is essential to the form of communication, we call this science communication. In our research projects, we focus on communication in action. What we call science communication here is therefore beyond (and partly prior to) the publication and reception of ready-made science qua scientific papers and refers to face-to-face situations (what we call in action).

\section{Videography and Focused Ethnography: Reconstructing Embodied Action}

Based on the strategy of "focused ethnography" (Knoblauch, 2005), we observed and videotaped science communication situations and analyzed their audiovisual representation later on in data sessions (Knoblauch et al., 2014). To validate our interpretation, we triangulated our findings with expert interviews, which provided us with important insights from the participants of the actual communicative situations (experts). We were therefore able to gain a complex picture of our research fields, which inspired us to focus on communicative actions. The use of audiovisual methodology is central to our research practice and has shown that contemporary science communication itself is largely shaped by visual practices. This poses a challenge to ethnographic fieldwork and makes video analysis an imperative part of an ethnographic 
investigation into science communication. First, both the visual and the bodily communicative actions of the actors are extremely volatile. A video analysis of communicative situations is therefore not only helpful but also necessary. Second, the visual in science communication occurs not only through bodily action (in communicative action) but also as an objectivation of meaning: "Communication is the kind of social action that is coordinated and synchronized by objectivations" (Knoblauch, 2013b, p. 261). Symbols and material objectivations used to communicate with others are (audio-)visualized (by speech and/or images) or are themselves visual (like objects). These elements challenge analysis because of their complex concurrent meaning structures and high degree of intercontextuality. We therefore analyzed our video data with sequence, hermeneutic, and genre analysis and triangulated this data with our ethnographic knowledge, gained in observations and expert interviews.

Our audiovisual data were analyzed through videography and media product analysis (Knoblauch et al., 2014). In the case of videography, we deal with video recordings of natural situations recorded by researchers for the purpose of methodological analysis. Media product analysis refers to the analysis of so-called process-generated data. In the case of the science slams, these are video recordings of the relevant events, which were produced by the organizers themselves and published on media platforms on the Internet. In the case of the group talks, the selection of the recorded lectures was strongly limited by the agreement of the respective scientists, so that not all group talks could be recorded in the observation phase. Nonetheless, full participation in all events during this period was made possible, ensuring that the data examples discussed here are representative. In the case of the science slams, the case selection was based on a quantitative evaluation. During the investigation period, the 10 most successful slams (measured by click counts) were selected.

Videography and media product analysis are not about the illusion that one can preserve "reality" in its entirety. Rather, the researchers must be aware of the fact that the video recording can show only a part of reality. Preliminary knowledge, field experience, and field survey expertise are therefore needed to guide video analysis. Our focused ethnography is therefore not based solely on video recordings but on a methodological triangulation which is typical of qualitative research designs. Our design combines videography, participant observation, expert interviews, and (to a lesser degree) document analysis. To supplement the videographic approach, the media product analysis of science slams presented here is triangulated with the analysis of 10 hours of interview material with science slam organizers (collected by Miira Hill), ethnographic experiences documented by several field protocols (also by Hill), and an analysis of the content of science slam websites. The benefits of this trianglulation will be demonstrated in the presentation of the case studies. For research in communication processes within the field of CNS, Wilke, additionally to the videotaped events, observed the regular meetings of the research group in CNS for 14 months (45 group talks in total). Fourteen hours of video data were recorded during the group talk. In addition, Wilke and colleague Eric Lettkemann performed twelve 90-min interviews with the aim of reconstructing knowledge and experience structures within this field. In addition, for contrast purposes, another 6 hours of an interdisciplinary humanities research colloquium were recorded and analyzed audiovisually. The research also showed that meticulous document analysis was necessary to gain a basic understanding and be able to contextualize the highly specified contents discussed in the field. In both cases, the interview data were analyzed by qualitative content analysis following Philipp Mayring (2010) using the software MAXQDA.

\section{The Communicative Construction of New Forms of Science Communication}

Our theoretical framework is closely related to our research paradigm. From a social constructivist's perspective, we refer to the latest elaboration on Berger and Luckmann's (1966) Social Construction of Reality: the communicative construction of reality (Keller, Knoblauch, \& Reichertz, 2013; Knoblauch, 2017). Communicative constructivism is based on a fundamental critique and therefore revision of prior social constructivist versions. It replaces the prefix social with the prefix communicative to focus on the actual modus of social construction in a more empirical fashion (Knoblauch \& Wilke, 2016). This approach regards action as communicative: "Because social action requires a form of objectivation allowing us to coordinate our conduct with that of others in a way that makes sense to others, it is, in fact, communicative action" (Knoblauch, 2013b, p. 162). In the face-to-face-communication of scientific knowledge, the role of informatization, digital media, and performance has become more accentuated. Objectivations of meaning in the form of visual representations and bodily expressions have therefore become the focus of our research.

From this perspective, the question arises as to how the increasing importance of visuality in communicative processes affects (the) social (construction of) reality. Communicative constructivism sees digitized information and its medialisation as deeply shaping modern societies (e.g., Couldry \& Hepp, 2013; Knoblauch, 2017; Traue, 2014). The communication society is defined by ubiquitous computerized communication processes and technological cascades of (re-)presentations of digital information bytes. 
We share the major assumptions of communicative constructivism within this empirical-theoretical framework. Our research projects focus on the empirical modes of interand transdisciplinary science communication within the frame of scientific knowledge production (Bechtel, 2004), (re-)presentation (Alać, 2008) and communication (Lettkemann, Wilke, \& Knoblauch, 2018). We have found that both these spheres are tremendously shaped by new communication practices and technologies of visualization. From this point of view, the contemporary visuality of science communication has an enormous importance for the construction of reality and cannot be negotiated within a methodological and theoretical frame that concentrates on words and texts. Thus, both bodies and objectivations (what others call artifacts) are intended to be acoustically and visually (audiovisually) perceived. Presenters are also aware of the importance of the visual for their presentations and act accordingly. Therefore, the means of communication cannot be seen as a distraction from what is thought to be the real message (Goffman, 1981). In our fields of investigation, visualization is part of the routine grounds (Garfinkel, 1967) of everyday action. This knowledge consists of routines of (esthetic) practice that involve situational performance (bodies), situated spaces, technological infrastructures, as well as digital information and its objectivation in signs and symbols. The relation between knowledge and visual practices is therefore interactive: Knowledge gives shape to visuality in science communication, whereas visual objectivations - by virtue of their virtual or material resistance and persistence - shape knowledge and further practices. Thus, what is said and what is shown cannot be separated without destroying the communicated message. Solely analyzing printed slides, as Tufte (2006) did in his critical analysis of the Columbia accident, indeed makes PowerPoint "evil." The fact is that both what is said and what is shown are elements of the intersubjective construction of meaning and therefore reality. This is why we have decided to deal with new forms of scientific discourse genres in their own right.

\section{Two Case Studies: Science Communication and Communication in Science}

As mentioned earlier, our data were collected in two different projects funded by the DFG: Data referring to science slams was collected within the $\mathrm{PhD}$ research project "Slamming Science. The New Art of Old Public Science Communication" (Miira Hill). Data referring to CNS and group talks were collected as part of the research project "Visual Communication in Science Based on a Case-Study in Computational Neuroscience" (principal investigator: Hubert Knoblauch) by René Wilke and Eric Lettkemann.

\section{Science Communication in (Transdisciplinary) Science Slams}

New genres of public science communication began to emerge in the 1980s. Events like TED Talks (invented in 1984 in the silicon valley), Café Philosophique (1992), ${ }^{2}$ and Café Scientifique $(1998)^{3}$ could be seen as the start of a communicative movement.

Recently, the number of public science events has multiplied and diversified (Hill, 2016). Public science communication events are designed to reinvent science communication by using popular and artistic formats. In events like science slams or lecture performances, scientists are asked to present their knowledge in new ways that address lay audiences. Some of these events can claim to attract huge audiences, despite their scientific content. The genre is presented by its proponents as new and better ways of legitimizing and communicating science. Popularized genres, like the German science slam for example, address a diverse audience and adopt stylistic strategies from poetry slams to present scientific findings in a competitive environment.

Inspired by the poetry slam, the science slam was established in 2006 in the German town of Darmstadt by the psychologist Alexander Deppert. ${ }^{4}$ The science slam is an institutionalized genre of communicative action, following set guidelines for actions and aesthetic practices, such as time limits, competition rules, the need to present new selfmade scientific content, the need to translate it, and the requirement to create emotional responses and establish a special atmosphere. These communicative acts generally name an occasion that creates a scientific need for action and enable an assessment of one's own research based on its social relevance. The talk has to tackle the basic communicative problem of differentiated societies to communicate the researcher's public practice of science as relevant for society. It addresses the communicative problem of presenting a scientific topic as accessible to and relevant for the audience (Hill, 2018).

\section{(Visual) Communication in (Interdisciplinary) CNS Group Talks}

Our second case deals with communication between scientists. But likewise, it is a field which allows the study of visualization in science communication in general. Today, scientists from many different disciplines are involved in CNS research. The term was coined by Eric L. Schwartz (1990) in the 1980s. Today, CNS is the predominant modus operandi and regarded as the spearhead of modern brain research. In a nutshell, CNS is an interdisciplinary field linking physics, statistics, and mathematics to investigate information processing in the (human) brain. In practical terms, it involves the computation of more or less biologically plausible mathematical models of neural systems, 
which has only been possible on a larger scale since the development of fast computers in the 1980s: "Technical achievements in designing fast, powerful and relatively inexpensive computing machines have made it possible to undertake simulation and modelling projects that were hitherto only pipe dreams" (Churchland, Koch, \& Sejnowski, 1993, p. 47).

Wilke observed researchers in an interdisciplinary research group of about 20 postdocs and doctoral students. Like the scientists at science slam events, they have a great need for communication. They struggle with differences between the knowledges and relevance systems of their colleagues in the CNS research group. As members of that group, the observed scientists must gain legitimacy for their individual research approaches, which are widely influenced by their original disciplinary orientation. In fact, the field of CNS as a "discipline" crystallizes around such communicative struggles. CNS is a typical example of what we call the communicative turn in science. In the observed research group, computer scientists engage in artificial intelligence research. They develop rather loosely biologically inspired models of particular brain functions (like recognition and learning) for implementation in robots. At the same time, the physicists and mathematicians in the research group are busy developing new computational models of brain functions with the aim of contributing to a general understanding of the human brain. Third, the team encompasses yet another field in which biophysicists and psychologists examine relatively established models with empirical data gained in experiments (this data is very often taken for reanalysis from neurobiological literature). In other words, the observed research group, just as the field itself and its relevant environment, has a heterogeneous structure.

But knowledge production in CNS is not only highly interdisciplinary but also very individualized. Researchers mostly work on their own, at their own computers, with data, programs, and above all visuals. Because the production of knowledge takes place in "isolation," the regular events when members of the group get together to discuss their findings are of particular significance. The research group has therefore established a particular "communicative genre" (Günthner \& Knoblauch, 1995; Luckmann, 1986) of scientific discourse, which they call group talk.

In the following, we will show that both our examples precisely correspond to research policy requirements for a stronger inter- and transdisciplinary orientation of science and take account of new science policy imperatives. In this sense, the definition of communicative genres as institutions of communication (Luckmann, 1986) corresponds very well to the empirical facts as it shows that science slams and group talks represent permanent solutions to the recurring structural problem of the need for inter- and transdisciplinary communication.

\section{Visuality in Science Communication}

We will now take a look at visuals in these two fields of science communication. In both, we can observe an increasing significance of the visual in science communication.

\section{Visuality in Science Slams}

The founder of the science slam launched the event with visual markers indicating that this event differs from a regular conference. Alongside the informal dress code (no suits allowed), the founder introduced a number of other unexpected items such as beer and a dispersed seating arrangement to create a different atmosphere (Hill, 2017).

At the onset of the German science slam movement in 2006, the talks were more paper oriented than slide oriented. There was an overhead projector on the stage and people stood close to the lectern (see Figure 1). Sometimes, they read from a paper. Over the years, visuals have greatly gained significance (see Figure 2). The presenters changed from text-spouting talking heads into full bodies in communicative action-performing and thereby orchestrating multimodal presentations in space and time. In that sense, audiovisual media resensualized the presentation of scientific knowledge in both genres (science slam and group talk). When a local institution for the advancement of public science in a middle-sized German city ("Haus der Wissenschaften" in Braunschweig) reinvented the genre in 2008 , they staged it with more visual tools from advertising. They utilized promotion tactics and designed a brain as the brand $\log$ o of the science slam. This logo later spread to other events. Correspondingly, over the years, the whole event became more focused on presentation software (e.g., PowerPoint, Presenter, Prezi, etc.) digital slides and visuals. Today, organizers ask participants to "consider bringing funny little pictures or install other punchlines," as a field expert puts it (MS49). ${ }^{5}$

In preparing their presentations, slammers started working with Google Images to illustrate their topic. In 2011, a few slammers leapt to fame with refined comic-style science slam presentations. Graduate student and cartoonist Kai Kuehne illustrated his seemingly cumbersome topic "Political trends in German labour law" and turned it into a cartoon. Giulia Enders' presentation "Darm mit Charm" (English: "Gut with Charm") from 2012 became another instant hit. Enders illustrated her presentation on digestion with the help of her sister Jill, a communication designer. The ubiquity of presentation software and help from visual experts increased the science slam scene's interest in using visual tools. Today, science slam organizers are very much aware of the impact of a good science slam presentation. In interviews, they enthuse about slammers with visually impressive presentations. In their opinion, the use of pictures distinguishes science slams from conventional science 


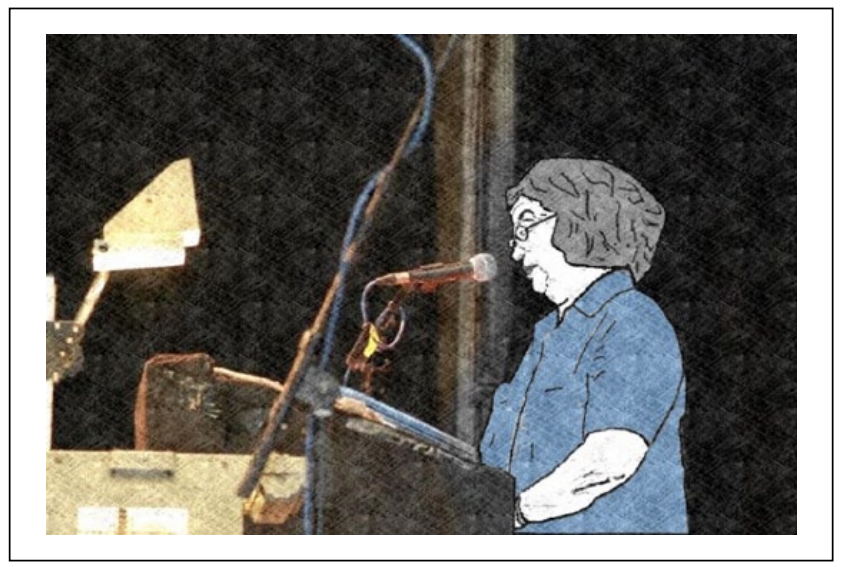

Figures I (anonymized). Image from the first science slam 2006.

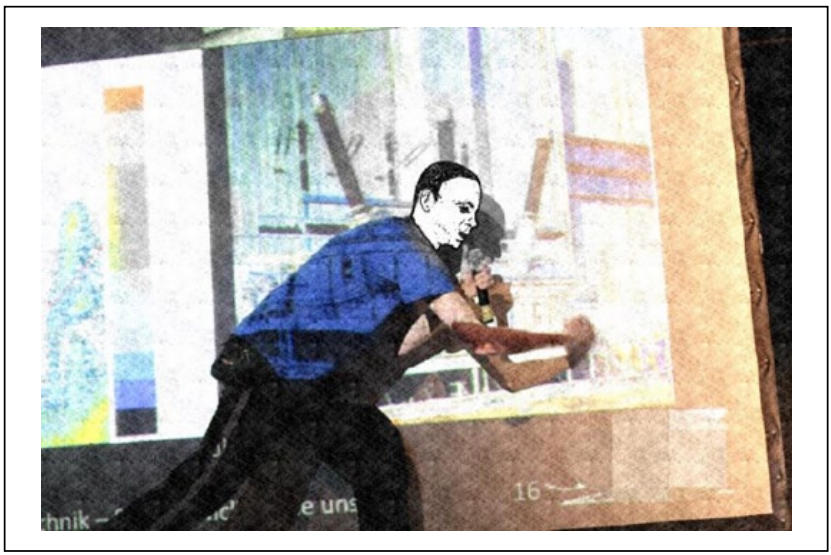

Figures 2 (anonymized). Image of a more recent science slam.

communication. Colorful pictures that have the potential to rouse feelings and grab audience attention are considered a competitive advantage. Visuals are described as a means of bringing speed into the talk. One organizer pointed out that "[p]ictures always bring ... good pictures, fast images, well fast cuts. Almost a little YouTubeish. Actually they are actually getting faster all the time" (MS48). ${ }^{6}$

The general lack of success (and visibility) of the humanities in the science slam context that has increased over the years is sometimes explained with their refusal or inability to work with visuals (cf. Hill, 2018).

\section{Visuality in Group Talks}

Inside the CNS research group, the ubiquity of visuals - as part of the interdisciplinary field of investigation - has been deeply internalized by all the actors involved. In a colloquial conversation after a group talk, two experts told us about an experience they had had, which they obviously found quite irritating: They were at an interdisciplinary conference, which included presentations by social scientists and philosophers. These presentations were "boring," so the experts told us, because they had no visuals, the presenters just read prepared manuscripts aloud. For the CNS researchers, this kind of presentation was a typical example of the lack of presentational knowledge, which is particular to the humanities. In the videographed group talks, in contrast, we observed a high significance of the visual. In an interview recently conducted with a leading U.S. computational neuroscientists (after a highly visualized talk she had just given), she told us:

Visualizing data? Yeah, I mean, it's really important . . . . I mean, that's kind of the first thing we do when we get new data, that we visualize it in a hundreds ways. Because we don't know what to think of it, right? . . . And that is really, I mean, that's like the fantastic part of it. When you visualize it in a new way and you see something that you didn't realize it was there. That's great! (EXP_6 $\left.{ }^{7}\right)$

As we can see, the visual representation of research objects in CNS is directly connected to the difficulties of research in the natural sciences and the problems ensuing from big data. Researchers visualize their quantitative objects of research (e.g., counts of [neuro-]electric activity) in terms of everyday objects like two- or three-dimensional shapes (e.g., spike trains), colors (e.g., heat maps), and geometric forms (e.g., spirals). Once measured and reduced to numbers, the object in question is reified as a digital visual. As such, it is opened up for interpretation and communication processes. The researcher becomes a hermeneutic (re-) presenter of (technological) aesthetics (e.g., MathLab). ${ }^{8}$ Therefore, successful researchers in the field have a very large degree of "visual literacy" (Goodwin, 1994) and "repräsentationales Wissen" [English: "representational knowledge"] (Wilke et al., 2018).

However, visualization in CNS is not only linked to special epistemological endeavors made necessary by big data; first and foremost, it is linked to the challenges of interdisciplinary communication. Referring to the meaning of visualization in presenting her work, the expert continued her account: "Well, I think it's the only way. That's how we explain our work. It's like showing plots of things" (EXP_6). Another expert gave us further insight into the meaning of visualization for gaining and communicating knowledge in the field of CNS. In an interview, he told us:

I always have to ask myself which part [of my work; R.W.] can I possibly represent, which part of it ... and which representation is informative. And then, in the context of writing new grant applications or giving talks, it's also important to consider which representation makes it look fancy. Which representation is suitable . . for a lay audience and most of all, does it sell? (EXP_2; translated from German [R.W.]) 


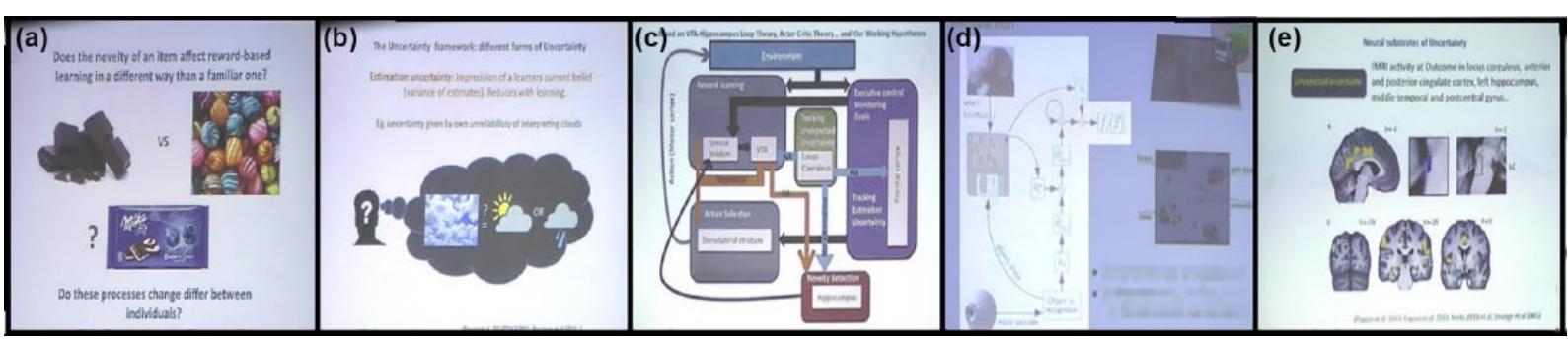

Figure 3. Typical visuals on digital slides in science communication: (a and b) metaphoric everyday images, (c and d) cybernetic representations, (e) standard statistical outputs.

In group talk situations, the speakers generally find it helpful to introduce the topic of the talk with metaphoric everyday images (often gathered through the Google Images search function). In describing a particular model, most presenters use cybernetic representational conventions. Finally, to evidence results, they use standard statistical diagrams such as graphs, heat maps, or functional magnetic resonance imaging (fMRI) images (see Figure 3). Cybernetic and statistical visuals bow to "Sehgewohnheiten" [English: "conventional patterns of seeing"] (Raab, 2008) and cross-disciplinary "visual literacy" (Goodwin, 1994) and are typically used in the observed group talks and more public CNS lectures, to sway audience opinion.

What we call presentational knowledge does not exclusively refer to knowledge about how to (re-)present digital information but equally to the ability to anticipate the "visual literacy" of the others, the ability to shape communication according to a specific "recipient design" (Sacks, Schegloff, \& Jefferson, 1974, p. 727). One biophysicist we interviewed put it like this:

Well I'm at conferences too about fMRI, neuroimaging or general neuroscience, and there you have people in the lecture theatre who are psychologists, psychiatrists, physicians, neurologists, biologists or mathematicians, and so I try to talk as intuitively as possible. I try to use a language where I have the feeling that everyone can understand approximately what I'm saying. It's about intuitive concepts and so on. But of course, you do want to talk about complex data and mechanisms and so you try to work as much as possible with images. I don't think it matters what discipline you come from, I think everyone can deal much better with images than tables and formulae, unless you happen to be talking to a party of mathematicians. (EXP_11; translated from German [R.W.])

In her statement, the expert explicitly confirms what the videography of her talks in the observed research team's group talk showed. Her tailored communication deliberately uses language intended to enable everyone to follow; visuals also seem to be her special means of translation. Her further statements suggest that the visualization of scientific knowledge as a translational tool in inter- and transdisciplinary contexts has a reciprocal effect on the communicative construction of evidence for subjective knowledge even in the narrower context of her own research group.

\section{The New Visual Repertoire in Science Communication}

In general, we noted that scientific communication is strongly influenced by visual practices in both our fields of research, the group talk and the science slam. Both are communicative genres that serve to convey scientific knowledge in heterogeneous contexts to a larger audience. The use of presentation software such as PowerPoint is obligatory for both genres: As a rule, no science slam or group talk can do without PowerPoint or similar programs. In both genres, visuals are just as ubiquitous as presentational software. It is not only a matter of serious, exact, and scientifically founded representations. Much more, the repertoire - of both genres, surprisingly - comprises a range of different forms of visuals. Within the scope of their pictorial repertoire or visual style, scientific representations like statistical visuals represent only a part.

Corresponding to the deliberate avoidance of professional jargon and emphasis on everyday language, vernacular images predominated over scientific images in the science communication we observed. Science slammers and researchers in the CNS group talk often use pictures gathered from Google Images - that is, generic visual topoi- to introduce their approach. The everyday images often relate to movies, TV, comics, sports, food, politicians, childhood, Internet, and animals. Visuals of experimental setups, gene codes, magnetic beads, blood samples, nerve cells, glia cells, bones, iron oxide, the brain, and very often statistical visuals such as diagrams, heat maps, and so on are also frequently used. Furthermore, presenters also like to show the tools they work with, like a scientific apparatus (MRT, Cern) or a device (syringe, petri dish) and visuals of the results they get (i.e., measurements). In both fields, what we call translational slides (Hill, 2016) are often used 
to bridge the gap between specialized scientific knowledge and common sense by showing the scientific visual and its metaphoric counterpart from everyday life together. Reminiscent of historical paintings showing scientists surrounded by their scientific tools or their colleagues, science slams often (and group talks sometimes) include images of the scientist's workplace or pictures of the researcher or research team in their work environment. With the help of these selected references, scientists translate, utilize, visualize, and embody their scientific subject matter while also claiming intersubjective evidence for their research results (Hill, 2016).

This stage of analysis already shows that a new visual repertoire has been established in science communication. In the following section, we will demonstrate how this increased significance of the visual is reflected in current science communication practices.

\section{Aesthetic and Visual Practices in Interaction}

Following our methodological design, we now present detailed descriptions and analyses of the aesthetic and visual practices in inter- and transdisciplinary science communication. Interestingly, many structures described using examples from science slams also apply to group talks and vice versa.

\section{The Aesthetics of the Settings}

The organizers of science slams enforce a certain "in-themaking" aesthetic (Hill, 2015). It is a typical feature of the genre that the audience can see the preparation of the staging. Not only do slammers have to set up their own presentations, the staging preparation of the event is also highly visible. In this way, the science slam pushes the rough-diamond style of science communication. The coaching offered by the organizers is not designed to produce uniformity. In interviews, organizers characterized good science slammers as communicative scientists who present their own research and have creative and artistic skills (Hill, 2017). Bad slammers were described as uncreative scientists presenting textbook knowledge they did not produce themselves and who copy the style of others or create uniformity. In group talks, the atmosphere is also highly informal. The genre has the character of a workshop. It represents a time and space in which the individual researchers in the group come together and present their results to each other, which they largely produced in isolation. Although the room is always the same, it always seems to have a makeshift character. This look is actually genuine because it is a typical seminar room, which is also used for teaching and other scientific purposes. The presenters thus always need a little time to set themselves up and connect their laptop to the technical infrastructure and so on. During this time, the other members of the group enter the room and take their seats. Many bring drinks and small snacks. One member of the group always comes with a large old-fashioned teapot. Everyone takes a casual sitting position, they chat or are busy with their smartphones until the research group leader enters the room and thereby gives the signal for the actual group talk to begin.

\section{Timing and Performance}

A typical characteristic of both communicative genres is the prominence of (staged) interaction (Hill, 2016). Like in all situations of copresence, the presenters in both fields constantly interact with their audience. Presentations are co-processed in a triadic structure, which unfolds between the presenter, his or her audience, and the objectivations used to communicate. As the objectivations in presentations rely partly on technological infrastructure, the presenter-audience interaction is necessarily coproduced with acts of presenter-machine interaction. These moments are typically well orchestrated: A click on the laptop or the remote control, often accompanied with a sideways glance toward the projected slide or the screen of the laptop, adds an objectivated time sequencing to the presentation. This technological rhythm underlies the entire presentation and its meaning is clear to the presenters and the audience alike. In both fields, presenters use the beat of the changing slide as a resource for sequencing the talk (e.g., presequence, general introduction, topic talk, excursus, results, closure) accompanied by prosodic changes and variations in pace. The audiences use these turning points (tropes) for interjections, questions, and comments. Often they ask to remain on the current slide or to skip back to a preceding one. Timing the interaction in the context of the triadic human-human-machine relationship (presenter, audience, hardware, and software of the presentation technology) is decisive in the sequencing of science slams and group talks.

As explained above, both communicative genres have a strongly argumentative dialogical character. In the observed group talks, everyone in the audience may ask questions or critique at any time. Such interjections do not even require a hand signal. Thus, we observed that a lecture can be divided into up to 80 "adjacency pairs" (e.g., questions and answers) in 45 min, following Sacks et al. (1974, p. 719). But still, the group talk genre is by no means dysfunctional. In the sense of an institution of communication, it serves the purpose of bringing scientists from heterogeneous backgrounds together within the frame of CNS. It is not until they put these communicative actions into practice that the institutional label of CNS applies. The fact that the argumentative dialogical character does not lead to communicative chaos is ensured by the timing. 


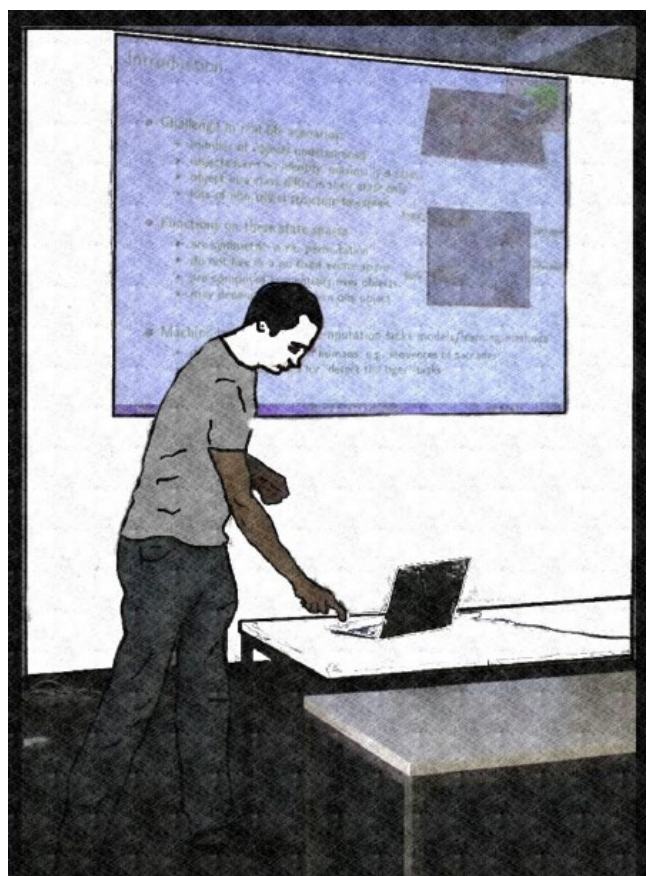

Figure 4. The iconic posture of changing the slide.

Although questions can be asked unannounced and at any time, the participants of the group talk also make use of the physical performance of the speakers - their movements in space and time - as a communicative resource for questioning, interjections, and critique. The image of a speaker (see Figure 4) stooping over the laptop, gaze fixed on the "next" button while trying to change the slide, is iconic in the visual communication of both communicative genres discussed here. However, this movement and the brief distraction of the presenter trying to switch the slide is a moment of respite for both sides. Both the speaker and the audience can use this interruption to sort the continuous flow of the previous dense communication. The presenter can focus better on the next point, whereas the audience, which has not yet seen the next slide, can use the break for a look back. The interruption is also an opportunity to ask a question in a moment which does not lead to the interruption of another speaker. To use these small breaks afforded by the slide-change for questions is therefore a polite gesture, which nevertheless has consequences for the presenter. Actually, presenters often find themselves caught in this position of changing the slide as cascades of questions are directed at them at this moment, interrupting the process again and again.

\section{Performance and Standing}

Science slams often have additional scripted interaction which generally involves questions from the speaker and an answer from the audience. The following short fragment of scripted interaction from a science slam shows how easily new visual orders can oblige the speaker to repair a situation to protect his or her standing: ${ }^{9}$

Slammmer: and the first thing cryptologists do, when they analyse an unknown (.) text, is count the letters. Does anyone know which letter is the most common in the German language? (points quickly to the audience with his left hand)

Audience: e:

Slammmer: E, exactly, so cryptologists always say, (throws his arms up) give me an? $(1,0)$

Audience: E:::

Slammmer: Exactly, and then they say, give me an $\mathrm{N}$ (clicks one slide forward. Frequency scales appear on the black background) and then give me an I and an S, and if you counted, (points to the slide on the side) then statistics are the result. And on the left side you can see what typical statistics (.) look like in German

Voice out of the audience: STEP BY SIDE

Audience: (laughs)

Slammmer: (looks down, goes one step to the left. Glances quickly to the slide on his right side) I=hope you can see it. So I hope I am more interesting than a statistic (points quickly with both hands to himself) (laughing)

This fragment shows a typical scripted interaction (Hill, 2016) in science slams. Slammers often enter the stage prepared with small question and answer sequences that they want to perform with the audience. Mostly, they pick questions that are not too complex and have a short predictable answer. ${ }^{10}$ In this sequence, we get the impression that the audience's attention is very focused on the slides. If the speaker obscures the view, the audience often speaks up to fix the problem, thwarting the speaker's best-laid plans. As in group talks, the audience in science slams feels encouraged to interrupt the speaker at any time. This new interaction order in science communication is more likely to produce a loss of face, as indeed it does on many occasions in both genres. One of the reasons for this is that - compared with the conventional lecture-power structures in contemporary science communication have decidedly loosened up. The audience in inter- and transdisciplinary contexts is allowed a voice in its own right, it has its own arguments and own demands, which can easily result in a loss of respect toward the speaker (Wilke \& Lettkemann, 2018).

Both genres are highly interactional, and actors with very different formal backgrounds permanently demand a shared relevance of the presented research questions and findings. The power gap which - according to Goffman-is still typical for the classic lecture is reduced in both genres discussed here. This is mirrored by the structure of 
turn-taking. The classic lecture is characterized by the fact that a narrator vocally reproduces a prearranged text and determines when to allow questions. In science slams and group talks, the presenter's turns are decidedly shorter and can become a pronounced staccato if the sheer number of queries swells the communication into what then resembles a cross-examination. In this sense, the respective recipient design in science slams and group talks is not one-sidedly oriented, ${ }^{11}$ rather it offers scope for exchanging ideas in a discourse that is much less hierarchical than the classic lecture. There is therefore no room for subject-specific conceit in the trans- or interdisciplinary framework of science communication. Rather, the entire communication process is oriented toward relationship building and understanding. In the first place, however, the speaker is the one who asks for understanding, whereas in the classic lecture, it is the listener who often enough is left struggling to understand.

\section{Conclusion: New Forms of Science Communication and Their Challenges for Methodology}

The visual is permanently rethought in the social sciences (see Bachleitner \& Weichbold, 2015; Blanc, 2013; Coopmans, Vertesi, Lynch, \& Woolgar, 2014; Knoblauch, 2008; Lynch \& Woolgar, 1990; Traue, 2013) for the simple reason that visual representational orders change permanently due to the emergence of new representational and communicational devices as well as new forms of (re-)presentation. In the sociology of science debate about the visual, it has recently been stated that in consequence of reflexive scientification and the imperative of inter- and transdisciplinarity, the impact of the visual in science has grown (Beck, 2013; Hill, 2016; Wilke \& Lettkemann, 2018). Our own empirical data has shown this to be true.

In this article, we stressed the communicative and translational character of the visual in science and the methodological requirements this entails. We looked at the use of visuals in inter- and transdisciplinary science communication as part of communicative action. In the first part, we addressed the theoretical and methodologically relevant question of how the visual affects the construction of reality. We then discussed examples from our empirical data concerning inter- and transdisciplinary science communication. Using the examples of CNS group talks and science slams, we demonstrated that visuals of scientific knowledge are used as translational tools. Both genres focus on digital slides and visuals. In both fields, we frequently observed the use of everyday images as well as the use of scientific visuals. In both fields, the refusal or inability to work with visuals is seen as a major reason for the failure of humanities to gain audiences in comparable formats. In the research group, we observed that the ubiquity of visualization plays a vital part in actually putting the interdisciplinary approach into practice. Not only opening arguments, research questions, and findings are regularly visualized but also the processes of collecting, preparing, and analyzing data are often illustrated by visuals (or a series of visuals) and presented with laptops, laser pointers, and presentation software. This applies to both genres we studied. In consequence, presenters in science slams and group talks need to performatively orchestrate their shows in space and time. The presenter's body is central not only as a speaking machine but also as a major tool to focus the audience's attention through the prefigured audiovisual objectified externalization of research results. In many disciplines, a form of presentational knowledge has developed which must be regarded as essential for the institutional visibility of scientists and scientific institutions themselves. Language and visualization must be tailored to the recipient to be heard and perceived as part of the scientific canon.

In terms of methodology, we arrived at this conclusion not by concentrating singularly on technologies of visualization, visual "content," or situated communicative practices but by bringing these three aspects together. By analyzing the technological aspects, we recognize the durable technological institutionalization of science communication; by considering the visuals themselves, it becomes clear that their use is only loosely tied to more traditional forms of science visualization (e.g., in the diagram or table); and by analyzing communicative practices, the embodiment of visualization and its institutionalized relevance was confirmed. This triangulation of methods enabled us to analyze different conditions and practices, which-working together-stabilize the transformation of science communication on three levels, which are closely intertwined with each other.

Through this research design and our research practice, we have been able to show that scientists today increasingly depend on visual practices in developing new knowledge and communicating it to others. Empirical studies of communicative practices in contemporary knowledge-based society have shown that the increased need to communicate with many others has resulted in "the ubiquity of PowerPoint" (Knoblauch, 2014). We would like to add that the ubiquity of visuals follows a similar path. Contemporary communication culture creates an order that is no longer based on faith in substantial truth but rather replaces written texts with visual patterns to get in touch with others, to convince them, and to gain legitimation for one's own standpoint (representational knowledge). As visual conventions grow, we find that legitimations are to a much greater extent performatively produced in communicative processes. The more central communicative work becomes, the more central the staging of the self (Soeffner, 2001), also in science, will be. Also, as MolekKozakowska (2018) points out, the public legitimacy of science is strongly affected by transdisciplinary communication strategies through "a distinct tendency on the part of science popularizers towards presenting bioscientific research as 
serving and benefiting an inordinate number of average people". Further studies on the transformation of scientific communication should carefully consider the methodological measures we have taken to understand how the social and cultural process we have studied is enacted, objectified, and institutionalized on different levels. The videographic approach allowed us to study closely the embodied communicative practices. In focused ethnographies, which are part and parcel of videographic data collection, the material staging of communication can be taken into account, which aids in interpreting the audiovisual data of videography. The expert interviews and document analyses allowed us to discern the situational practicalities of visualized science communication from institutional understandings of science, which serve to reinforce - or weaken - the visual characteristics of contemporary science communication.

Tantner (2013) formulates a harsh but accurate criticism of that development and names its drawbacks for the field of humanities. As a critic of neoliberalism, Tantner says that modern scholars are more than ever thrown back on themselves. Constant presentation constraints and the imperative of working on and presenting oneself determine (academic) everyday life. Against the background of this presentational duty (cf. Schnettler \& Knoblauch, 2007, p. 270), the whole body is progressively replacing the complacent staging of an omniscient voice from the ivory tower. Through our triangulated videographic approach, we can assert that indeed a performative self has taken center stage and that a number of situational constraints and institutionalized (presentational) norms are at play here. On another level, this visuality-driven subjectivation also extends toward users of technologies generated by scientists, as Urban (2018) demonstrates in her research on wearables in the health sector.

STS researchers have pointed to the question of how the power of science may relate to the visual tricks through which science is embodied. In Laboratory Life: The Social Construction of Scientific Facts (1979), Latour and Woolgar described a circle of credibility that a scientist uses to gain acceptance. Subsequently, Latour demonstrated that material differences help modern scientists to convince others. $\mathrm{He}$ argued that the reason why Western science is so powerful is because it uses a gigantic scientific instrument, a panopticon, which allows scientists to produce optical consistency. If today's Western scientists with nonvisual representational skills have to reckon with a loss of power, we may conclude that the scientific panopticon has been upgraded to include artistic and popularized devices. The art of convincing others today relies less on outlandish costumes and an incomprehensible language, as Berger and Luckmann pointed out only half-jokingly in 1966, and more on weapons from art, popular culture, and informatization. Haraway once opposed the "invisible conspiracy of masculine scientists and philosophers" and the "embodied others, who are not allowed not to have a body, a finite point of view" (Haraway, 1988, p. 575). Disembodiment and universal claims were described as part of the Western scientist's bag of "God-tricks" and as a view from nowhere. Today, scientists still use the God-trick to uphold power, but in inter- and transdisciplinary contexts, they additionally position themselves in performances of multimodal communicative actions. In situated settings of science communication, new interaction orders are loosening up old power structures and strengthening new ones, within which disciplinary God-tricks are increasingly supplemented with communicative visual practices, or as Latour (1990) put it, "You doubt what I say? I'll show you" (p. 36).

\section{Declaration of Conflicting Interests}

The author(s) declared no potential conflicts of interest with respect to the research, authorship, and/or publication of this article.

\section{Funding}

The author(s) disclosed receipt of the following financial support for the research, authorship and/or publication of this article: Both authors received financial support from the DFG (Deutsche Forschungsgemeinschaft [German Research Foundation]).

\section{Notes}

1. We borrow the term "visuals" from Morana Alać (2014), who suggested it as a generic form for various forms of visual representations.

2. Café Philosophique was founded by the French philosopher Marc Sautet 1992 in Paris. After the café was established in France, it spread to other countries.

3. A TV producer named Duncan Dallas heard of Café Philosophique and developed a similar format called Café Scientifique.

4. The poetry slam surfaced in the 1980 s in the United States in an attempt to democratize literature (Westermayr, 2004) and spread to Germany in the 1990s. Petra Anders' (2008) studies on poetry slams show that poetry slam performances often connect to daily news and everyday activities. The order of communication frequently includes audience interaction. For poetry slam presentations, melody is important, brevity is a rule, and there is a play with alienations (intertextuality).

5. From expert interview number 8 . The interviews carried out within the science slam project were enumerated chronologically starting with 42 .

6. From expert interview number 7. The interviews carried out within the science slam project were enumerated chronologically starting with 42 .

7. From expert interview number 6 . The interviews carried out within the CNS project were enumerated chronologically starting with 1 .

8. As Lorraine Daston and Peter Galison (2007) showed, the latest developments are only the tip of the iceberg in the process of permanent change in scientific representational orders in history.

9. The fragment was recorded at a science slam in Bochum in 2011. The presentation was delivered in German. 
10. Group talks have similar forms of predesigned interactions. However, these are strongly based on the stylistic device of the rhetorical question, and many speakers may hope that the audience will interpret the question as such and resist the urge to answer.

11. The new forms of visualized science communication we observe here correspond to the imperative of the "BeziehungsBild" [English: "image of relation"] (Blanc, 2012, 2013) which Mathias Blanc formulated for the documentary film. Blanc highlights the emancipatory power of documentaries made by filmmakers who see their (moving) pictures as social relations (Blanc, 2013, p. 330).

\section{References}

Alać, M. (2008). Working with brain scans: Digital images and gestural interaction in fMRI laboratory. Social Studies of Science, 38, 483-508.

Alać, M. (2014). Digital scientific visuals as fields for interaction. In C. Coopmans, J. Vertesi, M. E. Lynch, \& S. Woolgar (Eds.), Representation in scientific practice revisited (pp. 6188). Cambridge, MA: MIT Press.

Amann, K., \& Knorr-Cetina, K. (1990). The fixation of (visual) evidence. In M. Lynch \& S. Woolgar (Eds.), Representation in scientific practice (pp. 86-121). Cambridge, MA: MIT Press.

Anders, P. (2008). Texte und Materialien für den Unterricht. Slam Poetry [Texts and materials for teaching. Slam Poetry]. Stuttgart, Germany: Reclam.

Bachleitner, R., \& Weichbold, M. (2015). Zu den Grundlagen der visuellen Soziologie: Wahrnehmen und Sehen, Beobachten und Betrachten [On the foundations of visual sociology: Perception and seeing, observation and viewing]. Forum Qualitative Sozialforschung/Forum: Qualitative Social Research, 16(2), Article 10. doi:10.17169/fqs-16.2.2141

Beaulieu, A. (2002). Images are not the (only) truth: Brain mapping, visual knowledge, and iconoclasm. Science, Technology, \& Human Values, 27, 53-83.

Becher, T., \& Trowler, P. R. (2001). Academic tribes and territories: Intellectual enquiry and the cultures of disciplines (2nd ed.). Buckingham, UK: Society for Research into Higher Education.

Bechtel, W. (2004). The epistemology of evidence in cognitive neuroscience. Retrieved from https://mechanism.ucsd.edu/ epist.evidence.bechtel.july2004.pdf

Beck, G. (2013). Sichtbare Soziologie. Visualisierung und Wissenschaftskommunikation in der Zweiten Moderne [Visible sociology. Visualization and science communication in the second modernity]. Bielefeld, Germany: Transcript.

Berger, P. L., \& Luckmann, T. (1966). The social construction of reality. New York, NY: Anchor Books.

Blanc, M. (2012). Le savoir sociologique par l'image. Étude sur les conditions d'acceptabilité d'une épistémologie visuelle [Sociological knowledge by images. Study on the conditions of acceptability of a visual epistemology.]. Revue de L'Institut de Sociologie, 2010-2011, 29-36.

Blanc, M. (2013). Den filmischen Rahmen vergessen lassen oder aufdecken: Die soziologische Unterscheidung zwischen Dokumentarfilm und Reportage [Forgetting or revealing the filmic framework: The sociological distinction between documentary film and reportage.]. In P. Lucht, L.-M. Schmidt, \& R. Tuma (Eds.), Visuelles Wissen und Bilder des Sozialen: Aktuelle Entwicklungen in der Soziologie des Visuellen [Visual knowledge and images of the social. Recent developments in the sociology of the visual] (pp. 323-338). Wiesbaden, Germany: Springer.

Boehm, G. (1994). Was ist ein Bild? [What is an image?] München, Germany: Fink.

Callon, M. (1986). Some elements of a sociology of translation: Domestication of the scallops and the fishermen of St. Brieuc Bay. In J. Law (Ed.), Power, action and belief: A new sociology of knowledge (pp. 196-233). London, England: Routledge.

Churchland, P. S., Koch, C., \& Sejnowski, T. J. (1993). What is computational neuroscience? In E. Schwartz (Ed.), Computational neuroscience (pp. 46-55). Cambridge, MA: MIT Press.

Collins, R. (1998). The sociology of philosophies: A global theory of intellectual change. Cambridge, MA: Harvard University Press.

Coopmans, C., Vertesi, J., Lynch, M., \& Woolgar, S. (Eds.). (2014). Representation in scientific practice revisited. Cambridge, MA: MIT Press.

Couldry, N., \& Hepp, A. (2013). Conceptualising mediatization: Contexts, traditions, arguments. Communication Theory, 23, 191-202.

Daston, L., \& Galison, P. (2007). Objectivity. New York, NY: Zone Books.

Davies, S. R. (2009). Doing dialogue: Genre and flexibility in public engagement with science. Science as Culture, 18, 397-416.

Davies, S. R. (2013). Constituting public engagement: Meanings and genealogies of PEST in two U.K. studies. Science Communication, 35, 687-707.

Engel, A. (2018). Queer reading as power play: Methodological considerations for discourse analysis of visual material. Qualitative Inquiry, 25(4), 338-349.

Fleck, L. (2011). Über die wissenschaftliche Beobachtung und die Wahrnehmung im Allgemeinen [About scientific observation and perception in general]. In S. Werner \& C. Zittel (Eds.), Ludwik Fleck. Denkstile und Tatsachen. Gesammelte Schriften und Zeugnisse [Ludwik Fleck. Styles of thinking and facts. Collected writings and testimonies] (pp. 211-238). Frankfurt, Germany: Suhrkamp. (Original work published 1935)

Garfinkel, H. (1967). Studies in ethnomethodology. Englewood Cliffs, NJ: Prentice Hall.

Gibbons, M., Limoges, C., Nowotny, H., Schwartzman, S., Scott, P., \& Trow, M. (1994). The new production of knowledge: The dynamics of science and research in contemporary societies. London, England: Sage.

Goffman, E. (1981). Forms of talk. Philadelphia: University of Pennsylvania Press.

Goodwin, C. (1981). Conversational organization: Interaction between speakers and hearers. New York, NY: Academic Press.

Goodwin, C.(1994). Professional vision. American Anthropologist, 96, 606-633. 
Günthner, S., \& Knoblauch, H. (1995). Culturally patterned speaking practices-The analysis of communicative genres. Pragmatics, 5, 1-32.

Haraway, D. (1988). Situated knowledges: The science question in feminism and the privilege of partial perspective. Feminist Studies, 14, 575-599.

Hedenus, A. (2016). Embodiment and materialization in "neutral" materials: Using audio-visual analysis to discern social representations. Forum Qualitative Sozialforschung / Forum: Qualitative Social Research, 17(1), Article 3. doi:10.17169/ fqs-17.1.2404

Hill, M. (2015). Embodiment of science in science slams: A case of informal public science communication. In E. Stengler (Ed.), Studying science communication (pp. 18-23). Bristol, UK: Science Communication Unit.

Hill, M. (2016). Slamming science. The new art of old public science communication (Master's thesis), Technische Universität Berlin, Germany.

Hill, M. (2017). Science Slam und die (Re)Präsentation von Wissenschaft: Neue Einsichten des Kommunikativen Konstruktivismus über Wissenschaftskommunikation in der Popkultur [Science slam and the (re-)presentation of science. New insights into communicative constructivism on science communication in pop culture]. In J. Reichertz \& R. Tuma (Eds.), Der Kommunikative Konstruktivismus bei der Arbeit [Communicative constructivism at work] (pp. 187-217) Weinheim, Germany: Juventa Verlag.

Hill, M. (2018). Die Versinnbildlichung von Gesellschaftswissenschaft - Herausforderung Science Slam [The symbolization of social science-challenge science slam]. In S. Selke \& A. Treibel (Eds.), Öffentliche Wissenschaft und gesellschaftlicher Wandel [Public science and social change] (pp. 169-186). Wiesbaden, Germany: Springer.

Keller, R., Knoblauch, H., \& Reichertz, J. (Eds.). (2013). Kommunikativer Konstruktivismus. Theoretische und empirische Arbeiten zu einem neuen wissenssoziologischen Ansatz [Communicative constructivism. Theoretical and empirical work on a new approach of the sociology of knowledge]. Wiesbaden, Germany: Springer.

Kiesow, C. (2016). Die Mathematik als Denkwerk. Eine Studie zur kommunikativen und visuellen Performanz mathematischen Wissens [Mathematics as a work of thought. A study on the communicative and visual performance of mathematical knowledge]. Wiesbaden, Germany: Springer.

Knoblauch, H. (2005). Focused ethnography. Forum Qualitative Sozialforschung / Forum: Qualitative Social Research, 6(3), Article 44. doi:10.17169/fqs-6.3.20

Knoblauch, H. (2007). Die Performanz des Wissens. Zeigen und Wissen in der Powerpoint-Präsentation [The performance of knowledge. Showing and knowledge in the PowerPoint presentation]. In B. Schnettler \& H. Knoblauch (Eds.), Powerpoint-Präsentationen: Neue Formen der gesellschaftlichen Kommunikation von Wissen [PowerPoint presentations. New forms of social communication of knowledge] (pp. 117138). Konstanz, Germany: UVK.

Knoblauch, H. (2008). The performance of knowledge: Pointing and knowledge in PowerPoint presentations. Cultural Sociology, 2, 75-97.
Knoblauch, H. (2013a). Grundbegriffe und Aufgaben des Kommunikativen Konstruktivismus [Basic concepts and tasks of communicative constructivism]. In R. Keller, H. Knoblauch, \& J. Reichertz (Eds.), Kommunikativer Konstruktivismus. Theoretische und empirische Arbeiten zu einem neuen wissenssoziologischen Ansatz [Communicative constructivism. Theoretical and empirical work on a new approach of the sociology of knowledge] (pp. 25-47). Wiesbaden, Germany: Springer.

Knoblauch, H. (2013b). PowerPoint, communication, and the knowledge society. Cambridge, UK: Cambridge University Press.

Knoblauch, H. (2014). Communication, culture and PowerPoint. In H. Knoblauch, R. Tuma, \& M. Jacobs (Eds.), Culture, communication, and creativity: Reframing the relations of media, knowledge, and innovation in society (pp. 155-176). Frankfurt, Germany: Peter Lang.

Knoblauch, H. (2017). Die kommunikative Konstruktion der Wirklichkeit [The communicative construction of reality]. Wiesbaden, Germany: Springer.

Knoblauch, H., Tuma, R., \& Schnettler, B. (2014). Videography: Introduction to interpretive videoanalysis of social situations. Frankfurt, Germany: Peter Lang.

Knoblauch, H., \& Wilke, R. (2016). The common denominator: The reception and impact of Berger and Luckmann's the social construction of reality. Human Studies, 39, 51-69.

Knorr-Cetina, K. (2002). Wissenskulturen. Ein Vergleich naturwissenschaftlicher Wissensformen [Knowledge cultures. A comparison of scientific knowledge forms]. Frankfurt, Germany: Suhrkamp. (Original work published 1999)

Kuhn, T. S. (1972). Postskript - 1969 zur Analyse der Struktur wissenschaftlicher Revolutionen [Postscript-1969 for the analysis of the structure of scientific revolutions]. In P. Weingart (Ed.), Wissenschaftssoziologie 1: Wissenschaftliche Entwicklung als sozialer Proze $\beta$ [Sociology of science 1. Scientific development as a social process] (pp. 287-319). Frankfurt, Germany: Athenäum.

Latour, B. (1990). Drawing things together. In M. Lynch \& S. Woolgar (Eds.), Representation in scientific practice (pp. 1968). Cambridge, MA: MIT Press.

Latour, B., \& Woolgar, S. (1979). Laboratory life: The construction of scientific facts. Princeton, NJ: Princeton University Press.

Lettkemann, E., \& Wilke, R. (2016). Kommunikationsformen. Zur kommunikativen Konstruktion institutioneller Ordnungen am Beispiel des Group Talks in der Computational Neuroscience [Forms of communication. To the communicative construction of institutional orders using the example of group talk in computational neuroscience.] In N. Baur, C. Besio, M. Norkus, \& G. Petschick (Eds.), Wissen - Organisation - Forschungspraxis. Der Makro-Meso-Mikro-Link in der Wissenschaft [Knowledge-organization-research practice. The macro-meso-micro-link in science] (pp. 447-479). Weinheim, Germany: Beltz Juventa.

Lettkemann, E., Wilke, R., \& Knoblauch, H. (Eds.). (2018). Knowledge in action. Neue Formen der Kommunikation in der Wissensgesellschaft [Knowledge in action. New forms of communication in the knowledge society]. Wiesbaden, Germany: Springer. 
Luckmann, T. (1986). Grundformen der gesellschaftlichen Vermittlung des Wissens: Kommunikative Gattungen [Basic forms of social mediation of knowledge: communicative genres]. In F. Neidhardt, R. M. Lepsius, \& J. Weiß (Eds.), Kultur und Gesellschaft: Sonderheft 27 der Kölner Zeitschrift für Soziologie und Sozialpsychologie [Culture and society. Special issue 27 of the cologne journal of sociology and social psychology] (pp. 191-211). Opladen, Germany: Westdeutscher Verlag.

Lynch, M. (1988). The externalized retina: Selection and mathematization in the visual documentation of objects in the life sciences. Human Studies, 11, 201-234.

Lynch, M., \& Woolgar, S. (Eds.). (1990). Representation in scientific practice. Cambridge, MA: MIT Press.

Mayring, P. (2010) Qualitative Inhaltsanalyse [Qualitative content analysis] In G. Mey \& K. Mruck (Eds.), Handbuch Qualitative Forschung in der Psychologie [Handbook qualitative research in psychology] (pp. 601-613). Wiesbaden, Germany: VS Verlag für Sozialwissenschaften.

Mitchell, W. (1992). The pictorial turn. Chicago, IL: The University of Chicago Press.

Molek-Kozakowska, K. (2018). Making biosciences visible for popular consumption: Approaching image-text relations in Newscientist.com through a critical multimodal analysis. Qualitative Inquiry. Advance online publication. doi:10.1177/1077800418790296

Myers, N. (2008). Molecular embodiments and the body-work of modeling in protein crystallography. Social Studies of Science, 38, 163-199.

Myers, N. (2012). Dance your PhD: Embodied animations, body experiments, and the affective entanglements of life science research. Body \& Society, 18, 151-189.

Nowotny, H. (2003). Introduction: "Mode 2" revisited: The new production of knowledge. Minerva, 41, 179-194.

Nowotny, H., Scott, P., \& Gibbons, M. (2001). Re-thinking science: Knowledge and the public in an age of uncertainty. Oxford, UK: Polity Press.

Ochs, E., Gonzales, P., \& Jacoby, S. (1996). "When I come down I'm in the domain state": Grammar and graphic representation in the interpretive activity of physicists. In E. Ochs, E. Schegloff, \& S. A. Thompson (Eds.), Interaction and grammar (pp. 328-369). Cambridge, UK: Cambridge University Press.

Raab, J. (2008). Visuelle Wissenssoziologie: Theoretische Konzeption und materiale Analysen [Visual knowledge sociology. Theoretical conception and material analyzes]. Konstanz, Germany: UVK.

Rowley-Jolivet, E. (2004). Different visions, different visuals: A social semiotic analysis of field-specific visual composition in scientific conference presentations. Visual Communication, 3, 145-175.

Sacks, H., Schegloff, E., \& Jefferson, G. (1974). A simplest systematics for the organization of turn-taking for conversation. Language, 50, 696-735.

Schnettler, B., \& Knoblauch, H. (2007). Die Präsentation der 'Wissensgesellschaft'. Gegenwartsdiagnostische Nachüberle-gungen [The presentation of the "knowledge society." A time diagnostic consideration]. In B. Schnettler \& H. Knoblauch (Eds.), Powerpoint-Präsentationen: Neue Formen der gesellschaftlichen Kommunikation von Wissen [PowerPoint presentations. New forms of social communication of knowledge] (pp. 267-286). Konstanz, Germany: UVK.

Schwartz, E. L. (Ed.). (1990). Computational neuroscience. Cambridge, MA: MIT Press.

Shapin, S. (1990). Science and the public. In R. C. Olby, G. N. Cantor, J. R. R. Christie, \& M. J. S. Hodge (Eds.), Companion to the history of modern science (pp. 990-1007). London, England: Routledge.

Soeffner, H.-G. (2001). Authentizitätsfallen und mediale Verspiegelungen. Inszenierungen im 20. Jahrhundert [Authenticity traps and medial Mirror coatings. Staging in the 20th century]. In E. Fischer-Lichte (Ed.), Symposiumsband Theatralität und die Krisen der Repräsentation [Symposium theatricality and the Crises of representation] (pp. 165-176). Stuttgart, Germany: Metzeler.

Tantner, A. (2013). Das geschichtswissenschaftliche Weblog als Mittel des Selbstmanagements [The history-based weblog as a means of self-management]. In P. Haber \& E. Pfanzelter (Eds.), Historyblogosphere: Bloggen in den Geschichtswissenschaften [History blogosphere: blogging in history] (pp. 75-88). München, Germany: Oldenbourg.

Tibbetts, P. (1988). Representation and the realist-constructivist controversy. Human Studies, 11, 117-132.

Traue, B. (2013). Visuelle Diskursanalyse: Ein programmatischer Vorschlag zur Untersuchung von Sicht- und Sagbarkeiten im Medienwandel [Visual Discourse Analysis: A programmatic proposal to investigate visual and verbal expressions in media change.]. Zeitschrift für Diskursforschung, 1, 117-136.

Traue, B. (2014). Communication regimes and creativity. In M. Jacobs, H. Knoblauch, \& R. Tuma (Eds.), Culture, communication and creativity: Reframing the relations of media, knowledge, and innovation in society (pp. 227-246). Frankfurt, Germany: Peter Lang.

Trumbo, J. (1999). Visual literacy and science communication. Science Communication, 20, 409-425.

Trumbo, J. (2000). Essay: Seeing science: Research opportunities in the visual communication of science. Science Communication, 21, 379-391.

Tufte, E. R. (2006). The cognitive style of PowerPoint: Pitching out corrupts within. Cheshire, CT: Graphics Press.

Tuma, R. (2012). The (re)construction of human conduct: "Vernacular video analysis." Qualitative Sociology Review, 8, 152-163. Retrieved from http://www.qualitativesociologyreview.org/ENG/Volume22/QSR_8_2_Tuma.pdf

Urban, M. (2018). Visibilities and the analysis of interdiscourse: The case of digital health practices. Qualitative Inquiry, 25, 393-406.

Westermayr, S. (2004). Poetry Slam in Deutschland: Theorie und Praxis einer multimedialen Kunstform [Poetry slam in Germany. Theory and practice of a multimedia art form]. Marburg, Germany: Tectum.

Wilke, R., \& Lettkemann, E. (2018). Die Bewältigung interdisziplinärer Wissenskommunikation im Group Talk: Bausteine einer wissenssoziologischen Gattungsanalyse [Coping with interdisciplinary Knowledge communication in Group Talk: Elements of a genre analysis]. In E. Lettkemann, R. Wilke, \& H. Knoblauch (Eds.), Knowledge in action: Neue Formen der Kommunikation in der Wissensgesellschaft [Knowledge in action: New forms of communication in the knowledge society] (pp. 73-107). Wiesbaden, Germany: Springer. 
Wilke, R., Lettkemann, E., \& Knoblauch, H. (2018). Präsentationales Wissen [Presentational knowledge]. In E. Lettkemann, R. Wilke, \& H. Knoblauch (Eds.), Knowledge in action. Wissen, Kommunikation und Gesellschaft (Schriften zur Wissenssoziologie) [Knowledge in action. Knowledge, communication and society (Writings on the sociology of knowledge)] (pp. 239-272). Wiesbaden, Germany: Springer.

Woolgar, S. (1990). Time and documents in researcher interaction: Some ways of making out what is happening in experimental science. In M. Lynch \& S. Woolgar (Eds.), Representation in scientific practice (pp. 123-151). Cambridge, MA: MIT Press.

Yearley, S. (1994). Understanding science from the perspective of the sociology of scientific knowledge: An overview. Public Understanding of Science, 3, 245-258.

\section{Author Biographies}

René Wilke is a doctoral student at the Technische Universität Berlin, where he is a research associate. He is currently the scientific coordinator of an interdisciplinary project on the development of a research data infrastructure for audio-visual data from empirical social research. His special interests are qualitative research methods, communication research, and sociological theory.

Miira Hill, $\mathrm{PhD}$, is author of Slamming Science. The New Art of Old Public Science Communication (2016). Currently she is a research associate at the Leuphana University of Lüneburg. Her research focuses on the situated performance of scientists on stage and the justifications of their actions. She studied sociology at the Bielefeld University and the Technische Universität Berlin, receiving her $\mathrm{PhD}$ in sociology in 2016. 